\title{
Transition Metal-free Methylation of Amines with Formaldehyde as the Reductant and Methyl Source
}

\author{
Nikki Y. T. Mana, Wanfang Li ${ }^{b}$ Scott G. Stewarta, and Xiao-Feng Wu*b
}

\begin{abstract}
A simpletransition metal-free procedure using formaldehyde for the $N, N$-dimethylation and $N$-methylation of primary and secondary anilines is reported. The reaction showed limitations on sterically hindered and electronwithdrawing anilines, but is successful on amines with electron-donating substituents. Formaldehyde acts as both the reducing agent and the carbon source in the reaction.
\end{abstract}

Keywords: Anilines $\cdot$ Eschweiler-Clarke reaction $\cdot$ Formaldehyde $\cdot$ Metal-free $\cdot N$-methylation

$N$-Methylation of amines in organic synthesis is a simple yet important reaction due to its significance in the bulk and fine chemical industries because these amines are widely used as intermediates in the preparation of products such as dyes, pharmaceuticals and agrochemicals. ${ }^{[1]}$ Not only important in industry, $\mathrm{N}$-methylated compounds are also prevalent in naturally occurring and synthetic biologically active compounds such as $\mathrm{N}$-methylated peptides and amino acids; $; 2,3]$ the methylation of the nitrogen atoms regulate biological functions and is therefore considered one of the most important chemical modifications in natural science. ${ }^{[3]}$

Many general methodologies utilised for the methylation of amines in the laboratory require the use of activated methyl compounds, ${ }^{[4]}$ which are quite undesirable due to their high toxicity, as well as the generation of by-products and waste in the form of their organic and inorganic salts. Other common procedures for the methylation of amines require harsh conditions such as the use of different metal hydrides ${ }^{[5,6]}$ and metal ${ }^{[7]}$ or zeolite ${ }^{[8,9]}$

\footnotetext{
${ }^{\star}$ Correspondence: Prof. X. Wu

Tel.: +493811281343

E-mail: xiao-feng.wu@catalysis.de

a School of Chemistry and Biochemistry

The University of Western Australia

35 Stirling Hwy, Crawley WA 6009, Australia

bLeibniz-Institut für Katalyse e.V. an der Universität

Rostock, Albert-Einstein-Str. 29a

18059 Rostock, Germany
}

catalysts. $\mathrm{N}$-Methylation utilising $\mathrm{CO}_{2}$ as the $C 1$ source has also recently been reported by the Cantat, ${ }^{[10]}$ Klankermayer, [11] Leitner[12] and Beller groups.[13] Although these reactions are efficient and green, in an effort to provide an alternative procedure without the use of metals or catalysts, the $N$-methylation of amines under other mild conditions was investigated.

Formaldehyde is an excellent $C 1$ building block that is inexpensive, readily available and has been used in a variety of different organic transformations. [14] Dissolved in water under $200{ }^{\circ} \mathrm{C}$, formaldyde exists predominantly as its hydrated geminal diol, methandiol.[15] Under basic conditions, methandiol converts into formic acid by proton exchange. ${ }^{[16]}$ Under this environment, the presence of both formic acid and formaldehyde can initiate a classic Eschweiler-Clarke reaction which allows the preparation of tertiary amines from secondary and primary amines.

The advantage of the classicEschweilerClarke reaction is that it is a one-pot reaction that does not require the addition of metal catalysts and $\mathrm{CO}_{2}$ source. Herein, we report a transition metal-free methylation procedure which uses formaldehyde as both the reducing agent as well as the source of carbon.

Initially, the reaction conditions were optimised using $N$-methylaniline (1) as the standard substrate (Table 1). Upon heating a mixture of $\mathbf{1}$, formaldehyde $(37 \% \mathrm{w} / \mathrm{w}$, 10 equiv. $), \mathrm{K}_{2} \mathrm{CO}_{3}$ (0.2 equiv.) at $130{ }^{\circ} \mathrm{C}$ under an argon atmosphere in toluene, the conversion of 1 was greater than $99 \%$ with a yield of the dimethylated product (3) of $74 \%$ (Table 1, entry 1). Next, the reaction was performed with different equivalents of 1 (Table 1, entries 2-4). Unfortunately, the variation of the amount of substrate did not improve the yield of the reaction; however, with a reduced amount of $\mathbf{2}$, the conversion was as high as under the original conditions and the yield is comparable (Table 1, entry 3 ). The reaction was also performed under different temperatures (Table 1, entries 5-7).

A variety of inorganic bases was tested (Table 1, entries 8-13) which led to lower conversions and yields. Different organic bases were also tested (Table 1, entries 14-17) which led to $\mathrm{Et}_{3} \mathrm{~N}$ as the best candidate since the reaction produced the least amount of by-product. The equivalence of base was then altered to see its effects on the reaction (Table 1, entries 18-22). Although the conversion of substrate $\mathbf{1}$ is nearly quantitative, the yield is not; this is due to the formation of by-products 3 and 4, which comes from the Mannich reaction of the starting material with formaldehyde and methanol (Scheme 1). ${ }^{[17]}$ Comparisons with $\mathrm{K}_{2} \mathrm{CO}_{3}$ showed that the reaction does not succeed when there is a high equivalence of this base. In an attempt to reduce the amount of the by-products formed in the reaction, a higher equivalence of $\mathrm{Et}_{3} \mathrm{~N}$ was used which led to a slightly improved yield, and no by-product (Table 1, entry 24).

Length of the reaction time was varied (Table 1, entries 25-28), and 1,4-dioxane was tested as an alternative solvent (Table 1, entry 29). The optimised yield of $76 \%$ was achieved (Table 1, entry 28). Although comparable to the original conditions, the optimised conditions led to a minimal amount of by-product and a lower equivalence of formaldehyde is required.

As the reaction provided a moderate yield, an examination of the generality of this methylation protocol was performed. Unfortunately, the substrate scope turned out to be fairly limited. Non-substituted aryl amines were first examined (Table 2, en- 
Table 1. Optimization of the reductive methylation of $\mathrm{N}$-methylaniline (1)<smiles>C[NH2+]c1ccccc1</smiles>

1<smiles>C=O</smiles>

2<smiles>CN(C)c1ccccc1</smiles>

3

Entry 2 (equiv.) $\quad$ Base (equiv.) $\quad \mathrm{T}\left[{ }^{\circ} \mathrm{C}\right] \quad$ Time $[\mathrm{h}]$ Conversion [\%] 3 Yield [\% ${ }^{\mathrm{a}}$

\begin{tabular}{|c|c|c|c|c|c|c|}
\hline 1 & 10 & $\mathrm{~K}_{2} \mathrm{CO}_{3}(0.2)$ & 130 & 20 & $>99$ & 74 \\
\hline 2 & 4 & $\mathrm{~K}_{2} \mathrm{CO}_{3}(0.2)$ & 130 & 20 & 35 & 47 \\
\hline 3 & 8 & $\mathrm{~K}_{2} \mathrm{CO}_{3}(0.2)$ & 130 & 20 & $>99$ & 72 \\
\hline 4 & 16 & $\mathrm{~K}_{2} \mathrm{CO}_{3}(0.2)$ & 130 & 20 & 88 & 1.6 \\
\hline 5 & 8 & $\mathrm{~K}_{2} \mathrm{CO}_{3}(0.2)$ & r.t. & 20 & 18 & 2.2 \\
\hline 6 & 8 & $\mathrm{~K}_{2} \mathrm{CO}_{3}(0.2)$ & 70 & 20 & 42 & 5.2 \\
\hline 7 & 8 & $\mathrm{~K}_{2} \mathrm{CO}_{3}(0.2)$ & 110 & 20 & 94 & 69 \\
\hline 8 & 8 & $\mathrm{~K}_{2} \mathrm{~S}_{2} \mathrm{O}_{8}(0.2)$ & 130 & 20 & 0 & 0 \\
\hline 9 & 8 & 'BuOK (0.2) & 130 & 20 & 85 & 52 \\
\hline 10 & 8 & $\mathrm{Na}_{2} \mathrm{CO}_{3}(0.2)$ & 130 & 20 & 88 & 54 \\
\hline 11 & 8 & $\mathrm{NaOH}(0.2)$ & 130 & 20 & 86 & 59 \\
\hline 12 & 8 & $\mathrm{Cs}_{2} \mathrm{CO}_{3}(0.2)$ & 130 & 20 & 99 & 57 \\
\hline 13 & 8 & $\mathrm{NaHCO}_{3}(0.2)$ & 130 & 20 & $>99$ & 58 \\
\hline 14 & 8 & DBU (1.0) & 130 & 20 & 98 & 56 \\
\hline 15 & 8 & DIPEA (1.0) & 130 & 20 & 52 & 40 \\
\hline 16 & 8 & $\mathrm{Et}_{3} \mathrm{~N}(1.0)$ & 130 & 20 & 91 & 75 \\
\hline 17 & 8 & pyridine (1.0) & 130 & 20 & 98 & 18 \\
\hline 18 & 8 & $\mathrm{Et}_{3} \mathrm{~N}(0.1)$ & 130 & 20 & $>99$ & 11 \\
\hline 19 & 8 & $\mathrm{Et}_{3} \mathrm{~N}(0.4)$ & 130 & 20 & $>99$ & 16 \\
\hline 20 & 8 & $\mathrm{Et}_{3} \mathrm{~N}(0.8)$ & 130 & 20 & $>99$ & 46 \\
\hline 21 & 8 & $\mathrm{Et}_{3} \mathrm{~N}(1.0)$ & 130 & 20 & 98 & 61 \\
\hline 22 & 8 & $\mathrm{Et}_{3} \mathrm{~N}(1.5)$ & 130 & 20 & 98 & 64 \\
\hline 23 & 8 & $\mathrm{~K}_{2} \mathrm{CO}_{3}(1.5)$ & 130 & 20 & 2 & 1.7 \\
\hline 24 & 8 & $\mathrm{Et}_{3} \mathrm{~N}(5.0)$ & 130 & 20 & 97 & 71 \\
\hline 25 & 8 & $\mathrm{Et}_{3} \mathrm{~N}(5.0)$ & 130 & 2 & 77 & 22 \\
\hline 26 & 8 & $\mathrm{Et}_{3} \mathrm{~N}(5.0)$ & 130 & 4 & 88 & 40 \\
\hline 27 & 8 & $\mathrm{Et}_{3} \mathrm{~N}(5.0)$ & 130 & 8 & 90 & 53 \\
\hline 28 & 8 & $\mathrm{Et}_{3} \mathrm{~N}(5.0)$ & 130 & 16 & 99 & 76 \\
\hline $29^{b}$ & 8 & $\mathrm{Et}_{3} \mathrm{~N}(5.0)$ & 130 & 16 & 30 & 31 \\
\hline
\end{tabular}

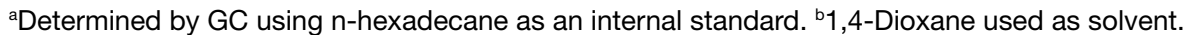

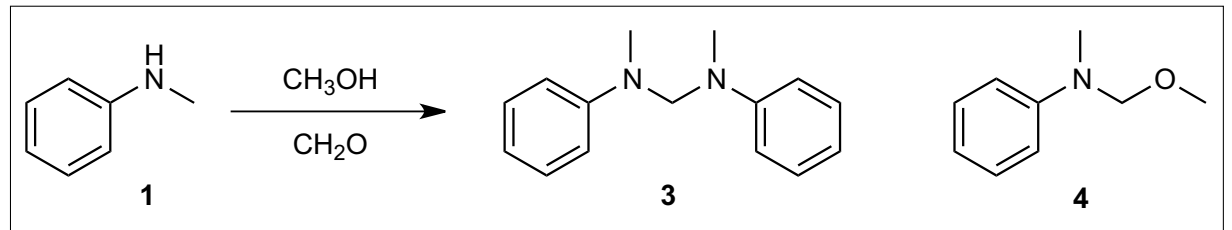

Scheme 1. Literature Mannich reaction of $N$-methylaniline with formaldehyde and methanol. ${ }^{[17]}$

tries 1-5) and the results show that the further away the $\mathrm{N}$-atom is from the aryl ring, the higher the yield. The presence of an $\mathrm{N}$-methyl group on the amine also increases the yield of the reaction as exemplified by the original reaction with $N$-methylaniline at $76 \%$ and $N$-methylbenzylaniline (Table 2 , entry 3 ) at $99 \%$, compared to their non-methylated counterparts at $13 \%$ and $57 \%$, respectively.

Sterically hindered amines were examined next. 2,4,6-Tri-tert-butylaniline and $N, N$ - diphenylaniline did not undergo methylation, and the slightly less sterically-hindered 2,6-dimethylaniline produced trace amounts of the monomethylated product and no dimethylated product. Saturated cyclic amines such as piperidine and 1-adamantylamine did not undergo methylation and the starting materials were decomposed in the reaction. Azepane and 2,6-tetramethylpiperidine, however, were successfully methylated at $92 \%$ and $89 \%$ yields, respectively (Table 2, entries 6,7). Saturated linear amines $N$-methyl-1,3propanediamine and ethylenediamine did not undergo methylation and the starting materials were decomposed in the reaction.

Subsequently, electronic effects were studied with anilines with a variety of substituents and substitution patterns. Anilines with strongly deactivating electron withdrawing substituents such as nitroanilines, aminobenzonitriles and 3-amino-4-trifluoromethylaniline did not undergo methylation. 2-Fluoroaniline and 2-bromoaniline did not undergo methylation, however, trace amounts of the mono- and dimethylated product of 4-chloroaniline were detected in GC-MS. 4-Bromoaniline was methylated, however, the reaction only produced a negliable yield of $0.5 \%$ (Table 2 , entry 8 ).

Anilines with electron-donating groups fared better in the methylation reaction. 4-Methoxy- $N, N$-dimethylaniline was isolated at $87 \%$ (Table 2, entry 9), and $N^{1}$ methyl- $N^{1}$-phenylethane-1,2-diamine was isolated at $60 \%$ yield (Table 2, entry 10 ). 3-(Methylamino)-1-phenyl-1-propanol was transformed into an imine under the given conditions.

Three indoles (1H-indole-2acetonitrile, tryptamine and 5-aminoindole) as well as 2,4-diaminotoluene were also examined without successful methylation and starting materials were decomposed in the reaction.

Although the reaction showed limitations on compounds that are sterically hindered and carry electron-withdrawing groups, this procedure is quite successful on amines in electron-donating environments. Formaldehyde is used as both the reducing and methylating reagent in this reaction and future work involving the use of ${ }^{13} \mathrm{C}$ labelled formaldehyde solution may lead to its applications in fluorescent tagging for biological evaluations.

\section{Acknowledgments}

We thank the general support from Prof. Matthias Beller.

Received: April 16, 2015 
Table 2. Methylation of different amines with formaldehyde.

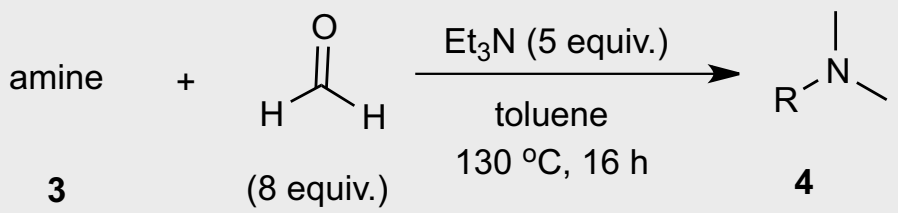

Entry

1<smiles>Nc1ccccc1</smiles>

2<smiles>NCc1ccccc1</smiles>

3<smiles>CNCc1ccccc1</smiles>

4<smiles>NCCc1ccccc1</smiles>

5<smiles>NCCCc1ccccc1</smiles>

6<smiles>C1CCCNCC1</smiles>

7<smiles>CC1(C)CCCC(C)(C)N1</smiles>

8<smiles>Nc1ccc(Br)cc1</smiles>

9<smiles>CNc1ccc(OC)cc1</smiles>

10<smiles>NCCNc1ccccc1</smiles>

4<smiles>CN(C)c1ccccc1</smiles><smiles>CN(C)Cc1ccccc1</smiles><smiles>CN(C)Cc1ccccc1</smiles>

[1] C. B. Singh, V. Kavala, A. K. Samal, B. K. Patel, Eur. J. Org. Chem. 2007, 1369.

[2] J. Chatterjee, C. Gilon, A. Hoffman, H. Kessler, Acc.Chem. Res. 2008, 41, 1331.

[3] J. Chatterjee, F. Rechenmacher, H. Kessler, Angew. Chem. Int. Ed. 2013, 52, 254.

[4] M. B. Smith, J. March, 'March's Advanced Organic Chemistry: Reactions, Mechanisms, and Structure', John Wiley \& Sons, 2007.

[5] R. F. Borch, A. I. Hassid, J. Org. Chem. 1972, 37, 1673.

[6] S. Bhattacharyya, Tetrahedron Lett. 1994, 35, 2401.

[7] K.-T. Huh, Y. Tsuji, M. Kobayashi, F. Okuda, Y Watanabe, Chem. Lett. 1988, 17, 449.

[8] M. Selva, A. Bomben, P. Tundo, J. Chem. Soc., Perkin Trans. 1 1997, 1041.

[9] M. Selva, P. Tundo, Tetrahedron Lett. 2003, 44, 8139.

[10] O. Jacquet, X. Frogneux, C. D. N. Gomes, T. Cantat, Chem. Sci. 2013, 4, 2127.

[11] K. Beydoun, T. vom Stein, J. Klankermayer, W. Leitner, Angew. Chem. Int Ed. 2013, 52, 9554.

[12] R. Fornika, H. Görls, B. Seemann, W. Leitner, J. Chem. Soc., Chem. Comm. 1995, 1479.

[13] Y. Li, X. Fang, K. Junge, M. Beller, Angew. Chem. 2013, 125, 9747.

[14] a) W. Li, X. F. Wu, Eur. J. Org. Chem. 2015 , 331 ; b) K. Natte, W. Li, H. Neumann, X. F. Wu, Tetrahedron Lett. 2015, 56, 1118.

[15] N. Matubayasi, S. Morooka, M. Nakahara, H. Takahashi, J. Mol. Liquids 2007, 134, 58.

[16] E. Norkus, R. Pauliukaite, A. Vaskelis, E. Butkus, Z. Jusys, M. Kreneviciene, J. Chem. Res.(S) 1998, 320.

[17] T. Shono, Y. Matsumura, K. Inoue, H. Ohmizu, S. Kashimura, J. Am. Chem. Soc. 1982, 104, 5753 .

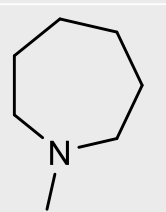<smiles>CN1C(C)(C)CCCC1(C)C</smiles><smiles>CN(C)c1ccc(Br)cc1</smiles><smiles>COc1ccc(N(C)C)cc1</smiles><smiles>CN(CCN)c1ccccc1</smiles> 